\title{
PENGARUH IDEOLOGI TERHADAP SIKAP RADIKAL PIMPINAN PONDOK PESANTREN DI TASIKMALAYA
}

\author{
Moh. Dulkiah \\ UIN Sunan Gunung Djati Bandung \\ Email: moh.dulkiah@uinsgd.ac.id
}

\begin{abstract}
Abstrak
Paham keagamaan sering kali dihubungkan dengan pandangan dan sikap seseorang atau kelompok yang dipengaruhi oleh ajaran agama dalam melihat persoalan yang dihadapi. Pandangan keagamaan dipengaruhi sumber ajaran, penafsiran, dan konteks yang ada di sekitarnya. Karena itu, paham keagamaan radikal dapat diukur dari seberapa literal dan keras seseorang atau kelompok dalam memahami agama dalam konteks sosial, politik, dan agama. Penelitian ini bertujuan untuk mengetahui pengaruh ideologi terhadap sikap radikal pimpinan pesantren di Tasikmalaya. Hasil penelitian menyimpulkan bahwa faktor ideologi berpengaruh signifikan terhadap radikalisme islam di kalangan pimpinan pondok pesantren di Tasikmalaya. Faktor ideologi berpengaruh terhadap radikalisme islam di kalangan pimpinan pondok pesantren di Tasikmalaya sebesar 32\% sedang sisanya sebesar 68\% dipengaruhi oleh variabel lain yang tidak diteliti dalam penelitian ini seperti ekonomi, pendidikan, dendam dan lain-lain.
\end{abstract}

Kata Kunci: Ideologi, Radikalisme, Pondok Pesantren, Tasikmalaya

\begin{abstract}
Religious understanding is often with people and people using key words. The religious view of the teacher, the interpretation, and the context that surrounds it. Therefore, understanding can produce results from many literal and loud individuals or groups in understanding religion in a social, political, and religious context. This study aims to determine the ideology for the radical attitude of pesantren in Tasikmalaya. The result of this research concludes that the ideology factor has significant effect on radicalism aligned by the leadership of pesantren in Tasikmalaya. Ideological factors against radicalism in the leader of pesantren leaders in Tasikmalaya by $32 \%$ are being released by $68 \%$ by other variables not examined in this study such as economy, education, revenge and others.
\end{abstract}

Keywords: Ideology, Radicalism, Pondok Pesantren, Tasikmalaya

\section{A. PENDAHULUAN}

Radikalisme agama adalah isu yang sangat menarik banyak perhatian, baik di dunia Internasional maupun di dalam negeri Indonesia sendiri. Di dunia Internasional, Agama Islam dianggap sebagai biang kerok dari beberapa peristiwa kekerasan dan teror di sejumlah negara. Sedangkan di dalam negeri Indonesia isu ini mencuat setelah seringnya bangsa ini didera aksi teror yang mengatasnamakan agama, di mana yang paling dikenang oleh masyarakat Internasional adalah peristiwa Bom Bali yang menewaskan begitu banyak Warga Negara Asing.

Isu-isu Radikalisme Agama di Indonesia selanjutnya sering dikaitkan dengan keberadaan Pondok Pesantren sebagai institusi pendidikan keagamaan tradisional. Pasalnya beberapa tokoh 
pelaku Radikalisme Agama tersebut adalah berasal dari kalangan Pondok Pesantren. Gerakangerakan Islam radikal selalu ada hubungannya dengan cara mereka memaknai jihad terutama dalam rangka melawan kemungkaran atau apa yang mereka anggap ketidakadilan. Gerakan Islam radikal juga berhubungan dengan agenda politik praktis atau politik kekuasaan dalam pengertian merebut, mempertahankan atau menghancurkan kekuasaan yang dinilai akan menghalangi tercapainya agenda politik mereka. Dalam rangka merebut kekuasaan, atau mendirikan Negara Islam mereka tidak segan-segan untuk menggunakan berbagai cara termasuk cara-cara kekerasan dan tindakan kriminal.

Sejarah mencatat bahwa Jawa Barat merupakan salah satu daerah yang pernah menjadi basis perjuangan untuk merebut kekuasaan dan mendirikan Negara Islam Indonesia (NII). Survey atau hasil penelitian awal menunjukkan bahwa sejumlah pesantren di Jawa Barat berpotensi menjadi basis tumbuhnya gerakan yang melahirkan kekerasan yang mengatasnamakan Islam. Penelitian awal juga menunjukkan bahwa Jamaah Islamiyah (JI), salah satu kelompok Islam garis keras yang berusaha mendirikan khilafah di Asia Tenggara juga menjadikan pesantren sebagai salah satu basis penanaman ideologi politik mereka.

Laporan terakhir dari International Crisis Group (ICG) yang berpusat di Brussels yang berjudul: Jamaah Islamiyah's Current Status, antara lain menyebutkan bahwa JI masih menyimpan cita-cita mendirikan Negara Islam Indonesia. Laporan itu juga menyebutkan bahwa kekuatan JI di berbagai wilayah di Indonesia akan ditentukan oleh berbagai faktor seperti adanya pesantren yang berafiliasi dengan JI, sejarah pemberontakan Darul Islam di daerah itu, hubungan bisnis dan kekerabatan di antara anggotanya, keberhasilan mereka dalam merekrut kader-kader dari lingkungan kampus, serta proses rekrutment yang terjadi dari dalam penjara.

Salah satu daerah yang terkenal dengan pesantrennya adalah Tasiklamaya. Tasikmalaya dikenal sebagai Kota Santri, khususnya di era sebelum 1980-an karena hampir di seluruh di wilayah ini tersebar pondok pesantren yang mengajarkan agama Islam, baik pondok besar maupun kecil, bahkan melahirkan tokoh perjuangan nasional di antaranya adalah Zainal Mustafa. Namun diduga sejumlah pesantren di Tasikmalaya masih mengembangkan paham keagamaan yang bisa dinilai sebagai bentuk ideologi Islam yang radikal.

Radikal berasal dari bahasa latin radix yang artinya akar. Dalam bahasa Inggris kata radical dapat bermakna ekstrim, menyeluruh, fanatik, revolusioner, ultra dan fundamental (Dictionary of Current English, 2000:691). Menurut Sartono Kartodirdjo (1985:38), radikalisme adalah gerakan sosial yang menolak secara menyeluruh tertib sosial yang sedang berlangsung dan ditandai oleh kejengkelan moral yang kuat untuk menentang dan bermusuhan dengan kaum yang memiliki hak-hak istimewa dan yang berkuasa.

Radikalisme yang dimaksudkan dalam tulisan ini adalah pemahaman-pemahaman keagamaan (Islam) radikal di kalangan pimpinan pesantren yang bercita-cita ingin melakukan perubahan besar dalam politik kenegaraan dengan menggunakan cara-cara kekerasan yang mengatasnamakan Islam. Perubahan besar dalam politik yang dimaksud adalah mengubah bentuk Negara Kesatuan Republik Indonesia (NKRI) menjadi bentuk Negara Islam Indonesia (NII).

Secara garis besar gerakan radikalisme disebabkan oleh faktor ideologi dan faktor nonideologi seperti ekonomi, dendam, sakit hati, ketidakpercayaan dan lain-lain. Faktor-faktor tersebut bisa menjadikan seseorang menjadi radikal, namun tidak semua faktor itu akan diteliti dalam penelitian ini, penelitian hanya akan memfokuskan pada faktor ideologi yaitu pemahaman keagamaan di kalangan pimpinan pesantren yang bisa memicu atau berpotensi menimbulkan gerakan radikal seperti pemahaman mereka tentang jihad, cara-cara menghadapi kemungkaran, 
ketidakadilan dan sejauh mana tindak kekerasan boleh diterapkan serta pandangan mereka tentang gerakan Darul Islam dan khilafah.

Faktor ideologi merupakan salah satu penyebab terjadinya perkembangan sikap radikal di kalangan pimpinan pesantren. Secara teoritis, orang yang sudah memiliki bekal pengetahuan setingkat pimpinan pesantren apabila memegang keyakinan yang radikal pasti sudah melalui proses mujadalah atau tukar pendapat yang cukup lama dan intens sehingga pada akhirnya mereka dapat menerima paham radikal tersebut. Faktor ideologi sangat sulit diberantas dalam jangka pendek dan memerlukan perencanaan yang matang karena berkaitan dengah keyakinan yang sudah dipegangi dan emosi keagamaan yang kuat. Faktor ideologi ini berpengaruh terhadap sikap radikal pimpinan pondok pesantren di Tasikmalaya.

\section{B. TINJAUAN PUSTAKA}

\section{Pengertian Radikalisme}

Radikal berasal dari bahasa latin radix yang berarti akar. Dalam bahasa Inggris kata radical dapat bermakna ekstrim, menyeluruh, fanatik, revolusioner, ultra dan fundamental (Dictionary of Current English, 2000:691). Sedangkan radicalism artinya doktrin atau praktik penganut paham radikal atau paham ekstrim (Nuhrison M. Nuh, 2009:36). Dalam Kamus Besar Bahasa Indonesia (1990:354), radikalisme diartikan sebagai paham atau aliran yang menginginkan perubahan dengan cara keras atau drastis.

Menurut Sartono Kartodirdjo (1985:38), radikalisme adalah gerakan sosial yang menolak secara menyeluruh tertib sosial yang sedang berlangsung dan ditandai oleh kejengkelan moral yang kuat untuk menentang dan bermusuhan dengan kaum yang memiliki hak-hak istimewa dan yang berkuasa. Radikalisme sering dimaknai berbeda diantara kelompok kepentingan.

Dalam lingkup keagamaan, radikalisme merupakan gerakan-gerakan keagamaan yang berusaha merombak secara total tatanan sosial dan politik yang ada dengan jalan menggunakan kekerasan (Rubaidi, 2007:33). Sedangkan dalam studi Ilmu Sosial, Radikalisme diartikan sebagai pandangan yang ingin melakukan perubahan yang mendasar sesuai dengan interpretasinya terhadap realitas social atau ideologi yang dianutnya (Husaini \& Naipospos, 2010:19). Dengan demikian, radikalisme merupakan gejala umum yang bisa terjadi dalam suatu masyarakat dengan motif beragam, baik sosial, politik, budaya maupun agama, yang ditandai oleh tindakan-tindakan keras, ekstrim, dan anarkis sebagai wujud penolakan terhadap gejala yang dihadapi.

Dari berbagai pengertian diatas, dapat disimpulkan bahwa yang dimaksud dengan radikal bila dilihat dari pemahaman agama, dan yang kami maksud dalam tesis ini adalah agama Islam, adalah gerakan yang berpandangan kolot dan sering menggunakan kekerasan dalam mengajarkan keyakinan mereka. Sementara Islam merupakan agama kedamaian yang mengajarkan sikap damai dan mencari kedamaian. Islam tidak pernah membenarkan praktek penggunaan kekerasan dalam menyebarkan agama, paham keagamaan serta paham politik.

\section{Ciri-Ciri Radikalisme}

Menurut Iwan Masqudi (2012:3), kelompok radikal memiliki ciri-ciri antara lain sebagai berikut:

Pertama sering mengklaim kebenaran tunggal dan menyesatkan kelompok lain yang tak sependapat. Klaim kebenaran selalu muncul dari kalangan yang seakan-akan mereka adalah Nabi yang tak pernah melakukan kesalahan ma'sum padahal mereka hanya manusia biasa. Klaim kebenaran tidak dapat dibenarkan karena manusia hanya memiliki kebenaran yang relatif dan 
hanya Allah yang tahu kebenaran absolut. Oleh sebab itu, jika ada kelompok yang merasa benar sendiri maka secara langsung mereka telah bertindak congkak merebut otoritas Allah.

Kedua, radikalisme mempersulit agama Islam yang sejatinya samhah (ringan) dengan menganggap ibadah sunnah seakan-akan wajib dan makruh seakan-akan haram. Radikalisme dicirikan dengan perilaku beragama yang lebih memprioritaskan persoalan-persoalan sekunder dan mengesampingkan yang primer.

Ketiga, kelompok radikal kebanyakan berlebihan dalam beragama yang tidak pada tempatnya. Dalam berdakwah mereka mengesampingkan metode gradual yang digunakan oleh Nabi, sehingga dakwah mereka justru membuat umat Islam yang masih awam merasa ketakutan dan keberatan. Padahal Allah menghendaki hal-hal yang meringankan dan tidak menghendaki hal-hal yang memberatkan umat-Nya.

Keempat, kasar dalam berinteraksi, keras dalam berbicara dan emosional dalam berdakwah. Ciri-ciri dakwah seperti ini sangat bertolak belakang dengan kesantunan dan kelembutan dakwah Nabi dalam (QS. 3:59). Dalam (QS. 6:25) Allah juga menganjurkan umat Islam supaya berdakwah dengan cara yang santun dan menghindari kata-kata kasar.

Kelima, kelompok radikal mudah berburuk sangka kepada orang lain di luar golongannya. Mereka senantiasa memandang orang lain hanya dari aspek negatifnya dan mengabaikan aspek positifnya. Hal ini harus dijauhi oleh umat Islam, sebab pangkal radikalisme adalah berburuk sangka kepada orang lain. Berburuk sangka adalah bentuk sikap merendahkan orang lain. Kelompok radikal sering tampak merasa suci dan menganggap kelompok lain sebagai ahli bid'ah dan sesat.

Keenam, mudah mengkafirkan orang lain yang berbeda pendapat. Di masa klasik sikap seperti ini identik dengan golongan Khawarij, kemudian di masa kontemporer identik dengan Jamaah Takfir wa al-Hijrah dan kelompok-kelompok puritan. Kelompok ini mengkafirkan orang lain yang berbuat maksiat, mengkafirkan pemerintah yang menganut demokrasi, mengkafirkan rakyat yang rela terhadap penerapan demokrasi, mengkafirkan umat Islam di Indonesia yang menjunjung tradisi lokal, dan mengkafirkan semua orang yang berbeda pandangan dengan mereka sebab mereka yakin bahwa pendapat mereka adalah pendapat Allah.

Rubaidi (2007:63), menguraikan 5 ciri gerakan radikalisme Islam diantaranya sebagai berikut:

a. Pertama, menjadikan Islam sebagai ideologi final dalam mengatur kehidupan individual dan juga politik ketata negaraan.

b. Kedua, nilai-nilai Islam yang dianut mengadopsi sumbernya di Timur Tengah secara apa adanya tanpa mempertimbangkan perkembangan sosial dan politik ketika AlQuran dan hadits hadir di muka bumi ini, dengan realitas lokal kekinian.

c. Ketiga, karena perhatian lebih terfokus pada teks Al-Quran dan hadits, maka purifikasi ini sangat berhati-hati untuk menerima segala budaya non asal Islam (budaya Timur Tengah) termasuk berhati-hati menerima tradisi lokal karena khawatir mencampuri Islam dengan bid'ah.

d. Keempat, menolak ideologi Non-Timur Tengah termasuk ideologi Barat, seperti demokrasi, sekularisme dan liberalisasi. Sekali lagi, segala peraturan yang ditetapkan harus merujuk pada Al-Quran dan hadith.

e. Kelima, gerakan kelompok ini sering berseberangan dengan masyarakat luas termasuk pemerintah. Oleh karena itu, terkadang terjadi gesekan ideologis bahkan fisik dengan kelompok lain, termasuk pemerintah. 


\section{Faktor Penyebab dan Sumber Kemunculan Radikalisme.}

Menurut Yusuf al-Qardawi (1406:59), radikalisme disebabkan oleh banyak faktor antara lain sebagai berikut:

a. Pengetahuan agama yang setengah-setengah melalui proses belajar yang doktriner.

b. Literal dalam memahami teks-teks agama sehingga kalangan radikal hanya memahami Islam dari kulitnya saja tetapi minim wawasan tentang esensi agama.

c. Tersibukkan oleh masalah-masalah sekunder seperti menggerak-gerakkan jari ketika tasyahud, memanjangkan jenggot, dan meninggikan celana sembari melupakan masalah-masalah primer.

d. Berlebihan dalam mengharamkan banyak hal yang justru memberatkan umat.

e. Lemah dalam wawasan sejarah dan sosiologi sehingga fatwa-fatwa mereka sering bertentangan dengan kemaslahatan umat, akal sehat, dan semangat zaman.

f. Radikalisme tidak jarang muncul sebagai reaksi terhadap bentuk-bentuk radikalisme yang lain seperti sikap radikal kaum sekular yang menolak agama.

g. Perlawanan terhadap ketidakadilan sosial, ekonomi, dan politik di tengah-tengah masyarakat. Radikalisme tidak jarang muncul sebagai ekspresi rasa frustasi dan pemberontakan terhadap ketidakadilan sosial yang disebabkan oleh mandulnya kinerja lembaga hukum. Kegagalan pemerintah dalam menegakkan keadilan akhirnya direspon oleh kalangan radikal dengan tuntutan penerapan syari'at Islam. Dengan menerapkan aturan syari'at mereka merasa dapat mematuhi perintah agama dalam rangka menegakkan keadilan. Namun, tuntutan penerapan syariah sering diabaikan oleh negara-negara sekular sehingga mereka frustasi dan akhirnya memilih cara-cara kekerasan.

Menurut Zada Khammami (2002:7), ia menjelaskan bahwa kemunculan radikalisme Agama (Islam Radikal) di Indonesia ditengarai oleh dua faktor. Pertama, faktor internal dari dalam umat Islam sendiri. Faktor ini terjadi karena adanya penyimpangan norma-norma agama. Kehidupan sekuler dalam kehidupan masyarakat mendorong mereka untuk kembali pada otentitas (fundamen) Islam. Faktor ini ditopang dengan pemahaman agama yang totalistic (kaffah) dan formalistik yang bersikap kaku dalam memahami teks-teks agama. Kajian terhadapa agama hanya dipandang dari satu arah yaitu tekstual, tidak melihat dari faktor lain, sehingga tindakan-tindakan yang mereka lakukan harus merujuk pada perilaku Nabi secara literal. Kedua, faktor eksternal di luar umat Islamyang mendukung terhadap penerapan syari at Islam dalam sendi-sendi kehidupan.

Menurut Endang Turmudzi, dkk. (2004:5), adanya radikalisme keagamaan sebenarnya merupakan fenomena yang biasa terjadi didalam agama apapun, radikalisme sangat berkaitan dengan fundamentalisme yang ditandai kembalinya masyarakat kepada dasar-dasar agama, fundamentalisme akan memnculkan radikalisme ketika kebebasan untuk kembali keagama dihalangi oleh situasi sosial-politik yang mengelilingi masyarakat. Fenomena ini akan menimbulkan konflik bahkan kekerasan antar dua kelompok yang berhadapan.

Menurut Azyumardi Azra (1993:5), radikalisme agama bertolak dari gerakan politik yang mendasarkan diri pada suatu doktrin keagamaan yang paling fundamental secara penuh dan literal bebas dari kompromi, penjinakan dan reinterpretasi (penafsiran).

Dalam masalah sumber radikalisme, Azyumardi Azra (2012:162), berpendapat bahwa dikalangan Umat Islam radikalisme itu banyak bersumber dari: 
a. Pemahaman keagamaan yang literal, sepotong-sepotong terhadap ayat-ayat Al-Quran. Pemahaman seperti itu hampir tidak Umumnya moderat, dan dan karena itu menjadi arus utama (mainstream) umat.

b. Bacaan yang salah terhadap sejarah umat Islam yang dikombinasikan dengan idealisasi berlebihan terhadapumat Islam pada masa tertentu. Ini terlihat dalam pandangan dan gerakan salafi, khususnya dalam spectrum sangat radikal seperti wahabiyah yang mncul disemenanjung Arabia pada akhir abad 18 awal sampai pada abad 19 dan terus merebak sampai sekarang ini. Tema pokok kelompok dan sel salafi ini adalah pemurnian Islam, yakni membersihkan Islam dari pemahaman dan praktek keagamaan yang mereka pandang sebagai bid`ah, yang tidak jarang mereka lakukan dengan cara-cara kekerasan.

c. Deprivasi politik, sosial dan ekonomi yang masih bertahan dalam masyarakat. Pada saat yang sama, disorientasi dan dislokasi sosial budaya, dan ekses globalisasi, dan semacamnya sekaligus merupakan tambahan faktor-faktor penting bagi kemunculan kelompok-kelompok radikal. Kelompok-kelompok sempalan tersebut tidak jarang mengambil bentuk kultus (cult) yang sangat eksklusif, tertutup dan berpusat pada seseorang yang dipandang kharismatik. kelompok-kelompok ini dengan dogma eskatologis tertentu bahkan memandang dunia sudah menjelang akhir zaman dan kiamat;sekarang sudah waktunya bertaubat melalui pemimpin dan kelompok mereka. Doktrin dan pandangan teologis-eskatolgis konflik sosial dan kekerasan bernuansa intra dan antar agama,bahkan antar umat beragam dengan Negara.

d. Masih berlanjutnya konflik sosial bernuansa intra dan antar agama dalam masa reformasi, sekali lagi, disebabkan berbagai faktor amat komplek. Pertama, berkaitan dengan euphoria kebebasan, dimana setiap orang atau kelompok merasa dapat mengekspresikan kebebasan dan kemauanya tanpa peduli dengan pihak-pihak lain. Dengan demikian terdapat gejala menurunya toleransi. Kedua, masih berlanjutnya fragmentasi politik dan sosial khususnya dikalangan elit politik, sosial, militer, yang terus mengimbas ke lapisan bawah (grassroot) dan menimbulkan konflik horizontal yang laten dan luas. Terdapat berbagai indikasi, konflik dan kekerasan bernuansa agama bahkan di provokasi kalangan elit tertentu untuk kepentingan mereka sendiri. Ketiga, tidak konsistennya penegakan hukum. Beberapa kasus konflik dan kekerasan yang bernuasa agama atau membawa simbolisme agama menunjukkan indikasi konflik di antara aparat keamanan, dan bahkan kontestasi diantara kelompokkelompok elit lokal. Keempat, meluasnya disorientasi dan dislokasi dalam masyarakat Indonesia, karena kesulitan-kesulitan dalam kehidupan sehari-hari. Kenaikan harga kebutuhan-kebutuhan sehari-hari lainnya membuat kalangan masyarakat semakin terhimpit dan terjepit. Akibatnya, orang-orang atau kelompok yang terhempas dan terkapar ini dengan mudah dan murah dapat melakukan tindakan emosional, dan bahkan dapat disewa untuk melakukan tindakan melanggar hukum dan kekerasan.

e. Melalui internet, selain menggunakan media kertas, kelompok radikal juga memanfaatkan dunia maya untuk menyebarkan buku-buku dan informasi tentang jihad. 


\section{METODE}

Penelitian ini bersifat verifikatif, yaitu penelitian kuantitatif yang bertujuan untuk menguji ada tidaknya pengaruh antar variabel. Populasi dari penelitian ini adalah seluruh pimpinan Pondok Pesantren di Tasikmalaya, yang di dalam penentuan sampel menggunakan metode Sistematic Random Sampling, yaitu dilakukan dengan cara mengambil sampel dengan cara mengacak menggunakan angka acak dimana peneliti terlebih dahulu menyusun daftar populasi sesuai dengan nama-nama berdasarkan abjad. Instrumen penelitian ini adalah menggunakan kuesioner. Data yang terkumpul melalui pembagian kuesioner diolah dengan teknik editing, koding, tabulasi. Teknik analisis data yang digunakan dalam penelitian ini menggunakan analisis regresi linier sederhana untuk menguji hipotesis.

\section{HASIL DAN PEMBAHASAN}

Radikalisme dapat diartikan sebagai paham keagamaan yang mengacu pada fondasi agama yang sangat mendasar dengan fanatisme keagamaan yang sangat tinggi, sehingga tidak jarang penganut dari paham/aliran tersebut menggunakan kekerasan kepada orang yang berbeda paham/aliran untuk mengaktualisasikan paham keagamaan yang dianut dan dipercayainya untuk diterima secara paksa.

Radikalisme sering dikaitkan dengan gerakan kelompok-kelompok ekstrim dalam suatu agama tertentu terutama Islam. Kaum muslimin membantah bahwa Islam adalah agama teroris, namun islam adalah agama kedamaian. Islam tidak pernah membenarkan praktek penggunaan kekerasan dalam menyebarkan agama, paham keagamaan serta paham politik. Banyak sekali tuduhan bahwa institui islam semisal pesantren adalah sarang teroris. Hal ini tidak seluruhnya salah, karena ada beberapa kasus terror yang melibatkan beberpa alumni pondok pesantren. Diduga sejumlah pesantren di Jawa Barat masih mengembangkan paham keagamaan yang bisa dinilai sebagai bentuk ideologi Islam radikal.

Secara garis besar gerakan radikalisme disebabkan oleh faktor ideologi dan faktor nonideologi seperti ekonomi, dendam, sakit hati, ketidakpercayaan dan lain-lain. Faktor-faktor tersebut bisa menjadikan seseorang menjadi radikal, namun tidak semua faktor itu akan diteliti dalam penelitian ini, penelitian hanya akan memfokuskan pada faktor ideologi yaitu pemahaman keagamaan di kalangan pimpinan pesantren yang bisa memicu atau berpotensi menimbulkan gerakan radikal seperti pemahaman mereka tentang jihad, cara-cara menghadapi kemungkaran, ketidakadilan dan sejauh mana tindak kekerasan boleh diterapkan serta pandangan mereka tentang gerakan Darul Islam dan khilafah.

Faktor ideologi merupakan salah satu penyebab terjadinya perkembangan radikalisme di kalangan pimpinan pesantren. Secara teoretis, orang yang sudah memiliki bekal pengetahuan setingkat pimpinan pesantren apabila memegang keyakinan yang radikal pasti sudah melalui proses mujadalah atau tukar pendapat yang cukup lama dan intens sehingga pada akhirnya mereka dapat menerima paham radikal tersebut. Faktor ideologi sangat sulit diberantas dalam jangka pendek dan memerlukan perencanaan yang matang karena berkaitan dengah keyakinan yang sudah dipegangi dan emosi keagamaan yang kuat.

Berdasarkan hasil penelitian tentang pengaruh ideologi terhadap sikap radikal pimpinan pondok pesantren di Tasikmalaya diketahui bahwa ada hubungan antara ideologi dengan sikap radikal pimpinan pondok pesantren. Hal ini dapat dilihat dari hasil analisis koefisien korelasi Product Moment Pearson dengan menggunakan SPSS 22 dalam tabel 1 sebagai berikut: 
Tabel 1 Analisis Koefisien Korelasi Variabel Ideologi dengan Sikap Radikal Pimpinan Pondok Pesantren di Tasikmalaya Correlations

\begin{tabular}{|lc|r|r|}
\hline & & Ideologi & Radikalisme \\
\hline \multirow{3}{*}{ Ideologi } & Pearson Correlation & 1 &, $566^{* *}$ \\
& Sig. (1-tailed) & &, 000 \\
& $\mathrm{~N}$ & 100 & 100 \\
Radikalisme & Pearson Correlation &, $566^{* *}$ & 1 \\
& Sig. (1-tailed) &, 000 & \\
& $\mathrm{~N}$ & 100 & 100 \\
\hline
\end{tabular}

**. Correlation is significant at the 0.01 level (1-tailed).

Sumber: Output SPSS 22, 2020

Berdasarkan hasil penelitian didapat nilai koefisien korelasi sebesar 0,566 yang menunjukkan bahwa antara variabel ideologi dengan sikap radikal pimpinan pondok pesantren di Tasikmalaya mempunyai hubungan yang positif dan berada tingkat hubungan yang sedang. Hubungan yang positif menandakan bahwa jika faktor ideologi jihad kuat, maka akan meningkatkan sikap radikal di kalangan pimpinan pondok pesantren di Tasikmalaya.

Ideologi adalah sistem kayakinan yang meliputi pemikiran teoritis (nazhari) dan pemikiran prakstis ('amali). Pemikiran teoritis berhubungan dengan benar dan salah, yakni bagaimana sebenarnya realitas, sedangkan pemikiran praktis berhubungan dengan baik dan buruk pada perbuatan manusia, yakni bagaimana seharusnya (must) dan tidak seharusnya (must not) manusia bertindak. Karena ideologi, secara umum berhubungan dengan pemikiran dan perilaku, maka ideologi selalu meliputi kehidupan manusia. Artinya, setiap manusia memiliki ideologi yang dipegang teguh olehnya, bahkan seseorang siap mengorbankan harta dan nyawanya demi memegang teguh ideologinya, terlepas ideologi itu benar atau salah.

Berdasarkan hasil analisis regresi linier sederhana kita bisa membuat prediksi mengenai peningkatan sikap radikali pimpinan pondok pesantren melalui faktor ideologi. Hasil analisis regresi antara ideologi terhadap sikap radikal pimpnan pondok pesantren dapat dilihat pada tabel 2 sebagai berikut:

Tabel 2 Analisis Regresi Linier Sederhana Variabel Ideologi Terhadap Sikap Radikal Pimpinan Pondok Pesantren di Tasikmalaya Coefficients $^{\mathrm{a}}$

\begin{tabular}{|c|c|c|c|c|c|c|}
\hline & \multirow[t]{2}{*}{ Model } & \multicolumn{2}{|c|}{$\begin{array}{c}\text { Unstandardized } \\
\text { Coefficients }\end{array}$} & $\begin{array}{c}\text { Standardized } \\
\text { Coefficients } \\
\end{array}$ & \multirow[t]{2}{*}{$t$} & \multirow[t]{2}{*}{ Sig. } \\
\hline & & $B$ & Std. Error & Beta & & \\
\hline \multirow{2}{*}{1} & (Constant) & 30,833 & 3,517 & & 8,768 & $\overline{000}$ \\
\hline & Ideologi & ,395 &, 070 & ,566 & 5,662 & ,000 \\
\hline
\end{tabular}

a. Dependent Variable: Radikalisme

Sumber: Output SPSS 22, 2020

Berdasarkan hasil analisis regresi linier sederhana didapat persamaan regresi yaitu $\hat{\mathrm{Y}}=$ $30,833+0,395 \mathrm{X}$ dengan signifikansi sebesar 0,000. Karena koefisien regresinya bernilai positif dan nilai signifikansinya kurang dari 0,05 , maka dengan hipotesis diterima atau terbukti yaitu: "Ada pengaruh yang positif dan signifikan antara ideologi terhadap sikap radikal pimpinan pondok pesantren di Tasikmalaya”. 
Konstanta sebesar 30,833 menyatakan bahwa apabila tidak ada kenaikan pada variabel ideologi atau variabel ideologi tetap, maka sikap radikal adalah sebesar 30,833. Sedangkan nilai koefisien regresi sebesar 0,395 menyatakan bahwa setiap kenaikan (karena tanda + ) 1 variabel ideologi, maka akan meningkatkan sikap radikal sebesar 0,395. Tanda + menyatakan arah hubungan yang searah, dimana kenaikan variabel ideologi (X) akan mengakibatkan kenaikan variabel sikap radikal (Y).

Paham keagamaan sering kali dihubungkan dengan pandangan dan sikap seseorang atau kelompok yang dipengaruhi oleh ajaran agama dalam melihat persoalan yang dihadapi. Pandangan keagamaan dipengaruhi sumber ajaran, penafsiran, dan konteks yang ada di sekitarnya. Karena itu, paham keagamaan radikal dapat diukur dari seberapa literal dan keras seseorang atau kelompok dalam memahami agama dalam konteks sosial, politik, dan agama.

Faktor ideologi berpengaruh cukup besar terhadap radikalisme islam di kalangan pimpinan pondok pesantren di Tasikmalaya. Hal ini dapat dilihat dari analisis koefisien determinasi pada tabel 3 sebagai berikut:

Tabel 3 Analisis Koefisien Determinasi Variabel Ideologi Terhadap Sikap Radikal Pimpinan Pondok Pesantren di Tasikmalaya Model Summary

\begin{tabular}{|c|r|r|r|r|}
\hline Model & \multicolumn{1}{|c|}{$\boldsymbol{R}$} & $\boldsymbol{R}$ Square & $\begin{array}{c}\text { Adjusted } \boldsymbol{R} \\
\text { Square }\end{array}$ & $\begin{array}{c}\text { Std. Error of } \\
\text { the Estimate }\end{array}$ \\
\hline 1 &, $566^{\mathrm{a}}$ &, 320 &, 310 & 3,51587 \\
\hline
\end{tabular}

a. Predictors: (Constant), Ideologi

Sumber: Output SPSS 22, 2020

Dari tabel diatas diketahui bahwa variabel ideologi (X) memberikan kontribusi terhadap sikap radikal pimpinan pondok pesantren di Tasikmalaya sebesar 32\% dan sisanya sebesar 68\% dipengaruhi oleh faktor-faktor lain yang tidak diteliti dalam penelitian ini misalnya ekonomi, pendidikan, dendam dan lain-lain.

Pesantren sebagai lembaga pendidikan keagamaan sejak dahulu memainkan peranan yang strategis dalam memengaruhi pola pikir, pengetahuan, pemahaman, dan perilaku keagamaan masyarakat Muslim di Jawa Barat. Tak berlebihan jika pesantren yang memiliki fungsi untuk membangun kerangka pikir dan perilaku masyarakat yang religius melakukan upaya revitalisasi ajaran agama dalam masyarakat modern. Namun demikian, mata pelajaran fiqh, tafsir, dan akidah/tauhid menyediakan konstruksi pemahaman keagamaan yang berpotensi pada kecenderungan pemahaman radikal, terutama dalam membahas persoalan jihad, kafir, dan hukum Islam. Jika konsepkonsep itu dipahami secara dogmatis dan radikal, akan memiliki potensi radikalisme. Namun bila dipahami secara kontekstual atau moderat, bisa meminimalisasi potensi radikalisme di Tasikmalaya.

\section{E. SIMPULAN}

Paham keagamaan sering kali dihubungkan dengan pandangan dan sikap seseorang atau kelompok yang dipengaruhi oleh ajaran agama dalam melihat persoalan yang dihadapi. Pandangan keagamaan dipengaruhi ideology jihad, sumber ajaran, penafsiran, dan konteks yang ada di sekitarnya. Hasil penelitian menyimpulkn bahwa faktor ideologi berpengaruh signifikan terhadap sikap radikali pimpinan pondok pesantren di Tasikmalaya. Faktor ideologi berpengaruh terhadap radikalisme islam di kalangan pimpinan pondok pesantren di Tasikmalaya sebesar $32 \%$ sedang sisanya sebesar $68 \%$ dipengaruhi oleh variabel lain yang tidak diteliti dalam penelitian ini seperti ekonomi, pendidikan, dendam dan lain-lain. 


\section{ARTIKEL}

\section{DAFTAR PUSTAKA}

Al-Qardhawi, Y. (1406). Al-Shahwah al-Islamiyah bayn al-Juhud wa al-Tattarruf. Cairo: Bank al-Taqwa.

Arikunto, S. (2009). Prosedur Penelitian. Jakarta: Rineka Cipta.

Azra, A. (1993). Memahami Gejala Fundamentalisme. Jurnal `Ulumul Quran, 4(3).

Departemen Pendidikan dan Kebudayaan Republik Indonesia. (1990). Kamus Besar Bahasa Indonesia. Jakarta: Balai Pustaka.

Hasani, I., \& Naipospos, B. T. (2010). Radikalisme Agama di Jabodetabek \& Jawa Barat: Implikasinya terhadap Jaminan Kebebasan Beragama/Berkeyakinan. Jakarta: Pustaka Masyarakat Setara.

Hornby, A. S. (2000). Dictionary of Current English. UK: Oxford University Press.

Kartodirdjo, S. (1985). Ratu Adil. Jakarta: Sinar Harapan.

Khammami, Z. (2002). Islam Radikal, Pergulatan Ormas-Ormas Islam Garis Keras di Indonesia. Jakarta: Teraju.

Masduqi, I. (2013). Deradikalisasi Pendidikan Islam Berbasis Khazanah Pesantren. Jurnal Pendidikan Islam, 1(2).

Mursalin, A., \& Katsir, I. (2010). Pola Pendidikan Keagamaan Pesantren dan Radikalisme: Studi Kasus Pesantren-Pesantren di Provinsi Jambi. Jurnal Kontekstualita, 25(2).

Nuh, N. M. (2009). Faktor-Faktor Penyebab Munculnya Faham/Gerakan Islam Radikal di Indonesi. Jurnal HARMONI, 8(2).

Rubaidi, A. (2007). Radikalisme Islam, Nahdlatul Ulama Masa depan Moderatisme Islam di Indonesia. Yogyakarta: Logung Pustaka.

Sugiyono. (2008). Metodologi Penelitian Kuantitatif, Kualitatif, dan R\&D. Bandung: Alfabeta.

Turmudzi, Endang, dkk. 2004. Islam dan Radikalisme di Indoneesia. Jakarta: LIPI Press. 